\title{
BLOOD PARASITE INFECTION PREVALENCE IN KAMPONG CHICKEN BREEDER'S GROUP IN GARUT
}

\author{
Djoko Legowo¹, Syifa Husnul Khotimah², and Lucia Tri Suwanti³ \\ ${ }^{1}$ Veterinary Pathology Department \\ ${ }^{2}$ Student \\ ${ }^{3}$ Veterinary Parasitology Department, Faculty of Veterinary Medicine, Universitas Airlangga
}

\section{Abstract}

The Aim of this research was to determine the blood parasite infection prevalence in Garut District. The research was conducted in November-December 2016. 160 samples of blood were obtained from eight subdistrict at Kampong Chicken Breeder's Group (KEPAK) in Garut District smeared with 3\% Giemsa solution and examined

Corresponding Author: Djoko Legowo

Received: 03 October 2017 Accepted: 10 October 2017 Published: 29 November 2017

Publishing services provided

by Knowledge

(a) Djoko Legowo et al. This article is distributed under the terms of the Creative

Commons Attribution License, which permits unrestricted use and redistribution provided that the original author and source are credited.

Selection and Peer-review under the responsibility of the VMIC Conference Committee.

\section{G OPEN ACCESS} under a microscope with 1000x magnification. The merozoite and gametocyte that was discovered recorded. The data that obtained was analyzed descriptively. A parasites were found in 11 blood samples (6.88\%). The genus of blood parasites is Leucocytozoon sp., while Plasmodium sp., Haemoproteus sp., and Trypanosoma avium sp. are not found in this research (0\%). All of blood infected parasite only found at Tarogong Kidul subdistrict and seven other subdistricts showed negative results.

Keywords: Blood parasite, Leucocytozoon, KEPAK, Kampong Chicken.

\section{INTRODUCTION}

Indonesia is known as a maritime country with high rainfall and heat (Utami et al., 2015). Global warming causing a climate and temperature changes that impact on environment damage as well as increasing on the appearance of various disease such as dengue and malaria. Climate change has also increased mosquitoes population who serves as a dengue and malaria's vector. It is because the temperature range $20^{\circ} \mathrm{C}-30^{\circ} \mathrm{C}$ is an ideal condition for reproduction of mosquito's i.e Anopheles sp., Aedes sp., and Culex sp. (Utami, 2015).

Until the recent infectious disease is still the world's health problems, especially in a tropical country and developing country, including in Indonesia (Sardjono, 2009). There are five a causal agent infection disease deeds bacteria, virus, rickettsia, fungi, and parasite (Prasetya, 2008). Poultry disease in particular chickens and ducks can be caused by a protozoan parasite. Plasmodium sp., Haemoproteus sp., and Leucocytozoon 
sp. are protozoan that parasitize within red blood cells, which can cause malaria poultry (Kurniantoro, 2011).

Leucocytozoon are epidemic in Java since 1994 (Julianti and Darjono, 1995). Leucocytozoonosis experience quite high spike to $5 \%$ of poultry disease total case in the field and had diagnosed in May till June 2001 (Wiryawan, 2002). In 2007, Leucocytozoonosis incidence appears in various endemic areas as East Java, Central Java, and South Kalimantan with varying severity levels (Ramadhan, 2014). Leucocytozoon sp. infection clinical symptoms on the farmed poultry in an acute form are lethargy, anemia, tachypnea, and leucositosis, reduced to appetite loss, green feces diarrhea, and CNS (Central Nervous System) disturbances.

Indigenous chicken Plasmodium spp.'s prevalence in Bogor was 54\%+23.44\% (Latipah, 2001). Plasmodium gallinaceum's infection rate on Bekisar chickens in Madura was $100 \%$ with $2.73 \%$ of parasitemia's average (Utami, 2015). Avian malaria manifestations vary from asymptomatic to a fast progressing acute form accompanied by severe anemia that can concluded with death. Beside, there are weakness, impaired breath, appetite loss, and short-term fever (Tabbu, 2002).

Haemoproteus prevalence in Queensland, Bulgaria, and U.S ranged between 20\%$32 \%$, whereas in Alaska less than 10\% (Samani et al., 2015). Haemoproteus reported has infected $23.3 \%$ chickens, 50.9\% pigeon, and 12.5\% quail in Bangladesh (Islam et al., 2013). Hoemoproteus infection reported has caused indigenous chickens's significant issue in Malawi (Fatima et al., 2014). H. meleagridis infection's clinical symptoms on turkey are lameness, diarrhea, emaciation, and anorexia while $H$. saccharovi's infected dove had a bile enlargement (Swayne, 2013).

T. avium and $T$. calmettei has been reported in chicken in Southeast Asia (Baker, 2007). T. avium's prevalence in the coastal area North of Norway is $26 \%$ whereas in inland area is $12 \%$ (Holmstad et al., 2003). T. avium's incidence of Eagle in Kuwait is 1.3\% (Tarello, 2005). Mosquitoes, simuliids, and hippoboscid flies were the T. avium's vector (Baker, 2007).

Garut district was reported free of poultry blood parasite disease but the disease occurrence in Selaawi and Cisurupan district has founded in October and November 2016. Mortality about $97 \%$ of Kampong chicken in Selaawi sub-district was occurred in October 2016 while mortality about 20\% in Cisurupan sub-district was occurred in November 2016. Newcastle disease is the mortality causes in Cisurupan sub-district's Kampong chicken while a causes in Selaawi sub-district is unknown. Garut district has a strategic position to supplies the needs of Bandung City and district residents as well as controlling an environmental balance. Garut breeders was developing breeders where 
the Kampong chicken was reared in a minimal population. The disease finding can be a potential risk to Garut breeders in the future.

The aim of this research was to determine the blood parasite infection prevalence in Garut District and each sub district of Garut District.

\section{RESEARCH METHOD}

The research was conducted at October until Desember 2016 in Kampong Chicken Farmers Group in Garut, and blood smear and Giemsa Staining in Al-Islam Hospital Bandung, and examination in Parasitology Department Laboratory Universitas Airlangga Surabaya. Determination of the sub-district in blood sampling based on its availability of Kampong Chicken in Garut District. Blood sampling of chicken was conducted in eight sub districts i.e: Wanaraja, Karangpawitan, Tarogong Kidul, Sukawening, Cilawu, Cisurupan, Cisompet, and Cikelet.

The research materials are the blood samples that taken from Kampong Chicken Breeder's Group in Garut. The other materials are absolute methanol pro analysis for the fixation of blood smear preparations, MERCK Cat ${ }^{\circledR} 1.09204 .0500$ absolute Giemsa solution as coloring agent, a Giemsa buffer solution as diluent for the absolute Giemsa solution, immersion oil, cotton, 70\% ethanol, and faucet water. Tools used in this research are 1 and $3 \mathrm{ml}$ syringe, $23 \mathrm{G}$ and $26 \mathrm{G}$ needle, suction tube (vacuum tube) EDTA $3 \mathrm{ml}$, a pipette, object glass, cover glass, baker glass, erlenmeyer, stirring-rod, filter paper, $2 \mathrm{~B}$ pencil, label, and a light microscope.

The research design used is descriptive studies. Purposive sampling was done from 160 chicken. 160 chicken originate from 8 district that each district sample was 20 chicken. The chicken held in a lying position, the head detained to one side and the wing opened. The part to be pierced is sterilized using cotton which already smeared with alcohol. The blood sample is obtained by putting a needle into brachialis vein at the chicken wing. Blood collected by vacuum tube and syringe as necessary (Martoenoes, 2012). Blood smear preparations are made by dripping chicken blood in the object glass and the cover glass pressed stably to shift the slope of 250-300 (Endrawati, 2012). Steps in Giemsa staining is the blood smear fixated with absolute methanol pro analysis, dipping and dyeing preparations in Giemsa 3\% solution for 30 minutes, washing with faucet water and aerated, the preparations spilled with immersion oil and then observed under microscope with 1000x magnification (10x ocular and 100x objective) (Solihat, 2002). 


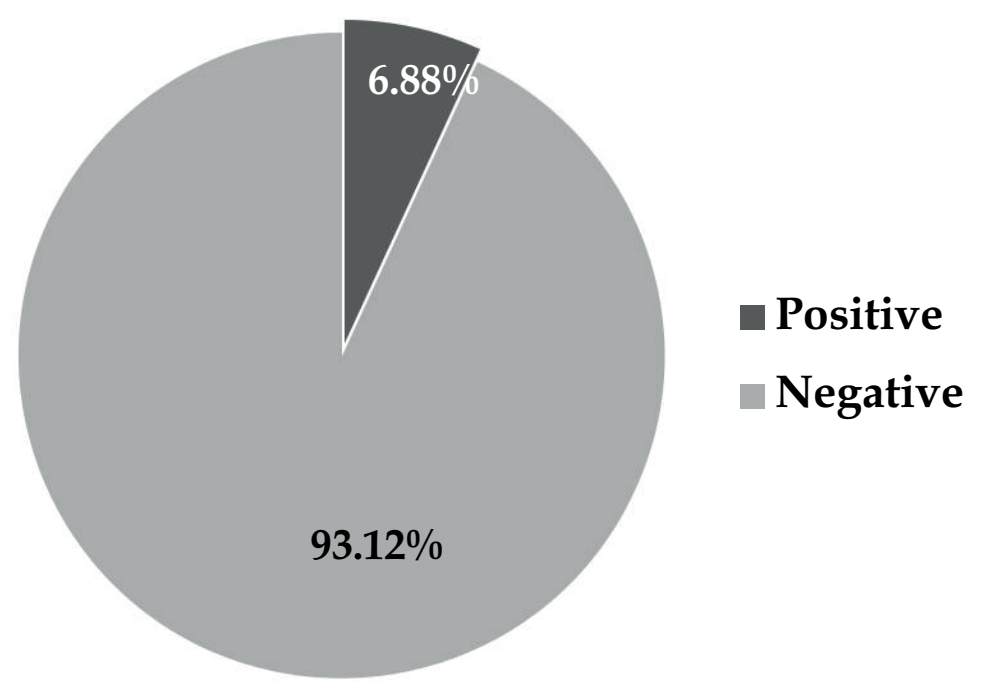

Figure 1: Blood parasite infection's percentage of Garut District.

\section{Blood Smear Preparation Examination}

Mixture which has been dyed then examined under microscope with magnification of 1000 times using immersion oil. Blood samples of Kampong Chicken which contained gametocytes phase Leucocytozoon sp. and Haemoproteus sp. confirmed positive infected with Leucocytozoon sp. and Haemoproteus sp. (Hadiputri, 2014). The blood sample of Kampong Chicken which contained trypomastigote phase Trypanosoma sp. confirmed positively infected by Trypanosoma sp. Chicken blood samples contained phase merozoites of Plasmodium sp. confirmed positively infected by Plasmodium sp.

The variables observed is the gametocytes and schizont phase of Leucocytozoon sp. in a leukocytes, the gametocytes and shcizont phase of Hoemoproteus sp. in an erythrocytes, merozoites and gametocyte phase of Plasmodium sp. in an erythrocytes, and trypomastigote stage of Trypanosoma sp. in chicken blood plasma. The identification results of the parasite positive and negative will be followed by prevalence formula.

The blood parasite prevalence data was displayed descriptively. Positive blood smear of chicken on an examination was calculated by using the prevalence formula. Acquired data then were tabulated and calculated with the formula in order to obtain the blood parasite infection prevalence on Kampong Chicken in Garut District.

\section{RESULT AND DISCUSSION}

The research has conducted on November to December 2016 using 160 Kampong Chicken blood smear samples in eight sub districts of Garut District. Eight sub district are 

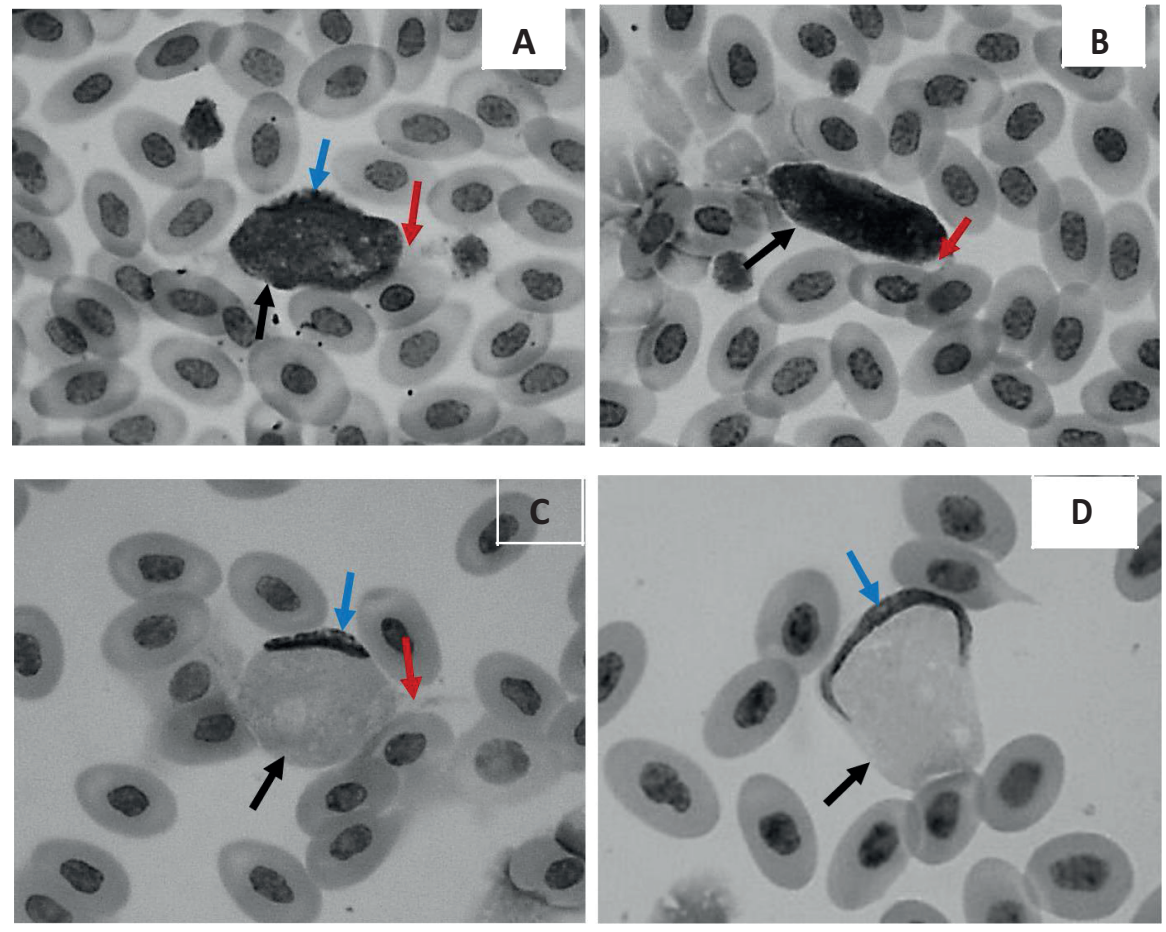

Figure 2: A-D Gametocyte ofLeucocytozoonsp.Black-arrow: parasite cell; red-arrow: host cell cytoplasm; blue-arrow: host cell nucleus (Giemsa staining; 1000x magnification).

TABLE 1: Eight sub district of Garut District differentiation based on place, population, altitude, and parasite finding.

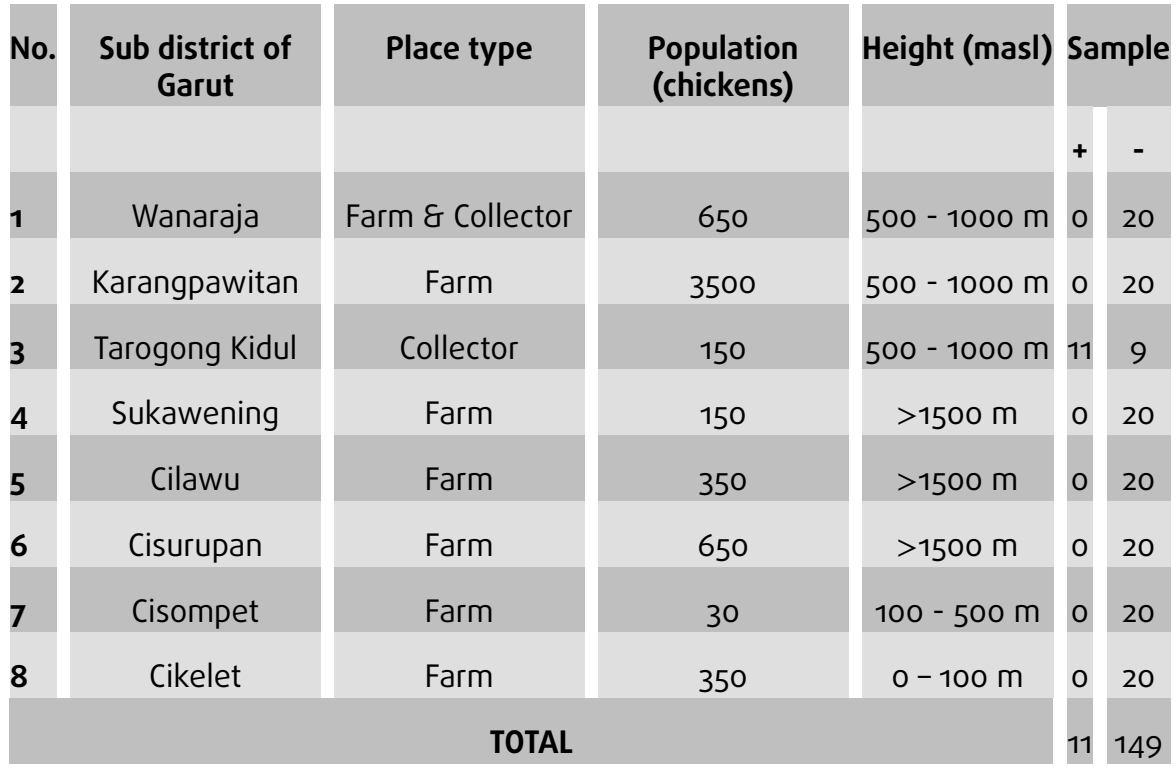

Wanaraja, Karangpawitan, Tarogong Kidul, Sukawening, Cilawu, Cisurupan, Cisompet and Cikelet. 20 chicken blood sample was taken from each sub district. Laboratory examination showed 11 positive samples infected with blood parasites or $6.88 \%$ of the total sample (Figure 1). A parasite found was Leucocytozoon sp. gametes such as in Figure 2 


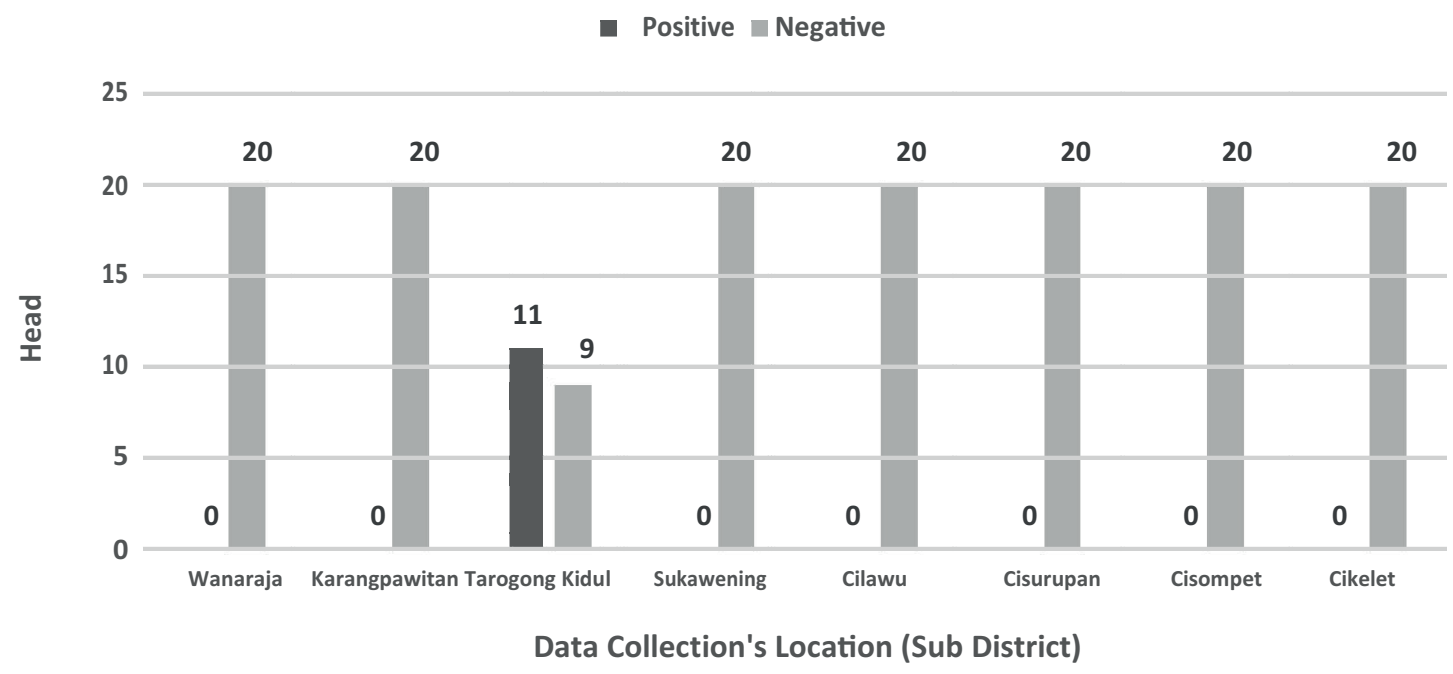

Figure 3: Column Chart of Leucocytozoon sp. Infection Prevalence in Garut's Sub-district.

The research conducted in eight sub districts in the Garut District using 20 samples per sub district. The observations showed 11 samples (55\%) of the infected blood by Leucocytozoon sp. was in Tarogong Kidul Sub district, while samples from other sub district weren't found blood parasite. Prevalence data of Leucocytozoon sp. infection of any sub district in Garut then presented in bar chart as Figure 3.

This result describes that prevalence of the Leucocytozoon sp. infection in Garut District is quite low. It show a different with previous research conducted by Saragih (2006) and Hadiputri (2014) but show quite similar with Rosdesiana's (2016) research. The recent research prevalence of Leucocytozoon infection was $6.88 \%$ while in Jombang was $10 \%$. The prevalence of Leucocytozoon infection in Surabaya traditional market was $42 \%$ while in Palangkaraya was $35 \%$. Central Kalimantan is medium endemic areas while the West Java is a low endemic malaria (Yuwanto, 2009). Endemic malaria area in Garut District was Cibalong, Pameungpeuk, Pakenjeng, Mekarmukti, Caringin and Bungbulang sub district (Farihatun and Mamdy, 2016). The highest prevalence in Surabaya and Palangkaraya market was caused by an origin place of chicken. Surabaya and Palangkaraya type place was a market where the chicken may come from every place, while Garut district and Jombang city was a farm, where the chicken come from a certain place.

The research of broiler chicken infected by Leucocytozoon coulleryi that conducted by Sinulingga and Darjono (2004) showed the merozoite appeared on 10th day and gametocytes on the 17th day after the sporozoite infection. Kampong chicken located in Tarogong Kidul sub district lives within 5 days, then the chicken being cut or sold. Leucocytozoon infection occurs on supplier of Tarogong Kidul, not in Tarogong Kidul District. Environmental conditions on farms contributes a lot to the Leucocytozoon infections 
incidence. The infection has already occurred at the time of the Kampong chicken DOC (day old chick) arrived at the farm. Tarogong Kidul Kampong chicken was originated from Garut district and other cities collector. A Tarogong Kidul supplier was Tasikmalaya breeder and Yogyakarta breeder. Ratnadewi (2015) stated that malaria endemic area in West Java Province was Garut, Tasikmalaya, Sukabumi, and Pangandaran District. In addition, Kulon Progo District and Purworejo Subdistrict Yogyakarta hasn't free form malaria disease (Rusqiyati, 2014). Yogyakarta breeder was surrounded by a river, a garbage disposal, a dirty chicken coop, and a garden where a plantation wasn't well taken care of. The supplier of Tarogong Kidul collector may sold a sick chicken. The parasite finding can be indicated two point, first it can showed that the blood parasite infection of Garut District hasn't detected or a parasite finding in Garut District was originated from Tasikmalaya and Yogyakarta breeder. It was estimated that a causes of outbreaks in Garut Kota and Sukawening subdistrict in Januari 2017 was Kampong chicken that originated from Tasikmalaya and Yogyakarta breeder. Garut government should keep on guard on poultry distribution that can initiate malaria infection appearance in the Kampong Chicken of Garut. A control and detection of disease should be done gradually until the infection data was recorded and the disease problem was solved.

\section{CONCLUSION}

Blood parasites infection prevalence in Garut i.e. 6.88\%. Prevalence rate of blood parasite infections in every sub-district in Garut District, namely Tarogong Kidul District as much as $55 \%$ while Wanaraja sub-district, Karangpawitan, Sukawening, Cilawu, Cisompet and Cikelet as much as $0 \%$.

\section{References}

[1] Farihatun, A., and Mamdy, Z. 2016. Faktor-Faktor yang Berhubungan dengan Perilaku Pencegahan Penyakit Malaria pada Masyarakat di Desa Karyamukti Kecamatan Cibalong Kabupaten Garut Provinsi Jawa Barat. Jur. Kes. Bak. Tun. Husada. 15(1): $109-121$.

[2] Julianti, D. and Darjono. 1995. Laporan Kasus: Wabah Leucocytozoonosis pada Ayam Pedaging dan Petelur di Jawa mulai Tahun 1994. Bul. FKH UGM 17(2): 103 - 109.

[3] Latipah, Y. 2001. Infeksi Parasit-Parasit Darah (Plasmodium spp., Leucocytozoon sabrazesi dan Leucocytozoon caulleryi) Secara Alami Pada Ayam Kampung yang 
Berasal dari Peternakan Rakyat Desa Sidang Sari, Bogor [Skripsi]. Fakultas Kedokteran Hewan. Institut Pertanian Bogor.

[4] Mufasirin, Lastuti, N. D. R., Suprihatin, E., and Suwanti, L. T. 2011. Bahan Ajar Ilmu Penyakit Protozoa. Departemen Parasitologi Veteriner Fakultas Kedokteran Universitas Airlangga. Surabaya. 32 - 34.

[5] Rahardjo, Y., Priambodo, T. E., and Suharno, B. 2002. Mengendalikan Penyakit Mirip Malaria (Leucocytozoonosis): Perkawinan Pencegahan dengan Pengobatan. Mengendalikan Penyakit Unggas. Infovet Ed.1. Jakarta. 244-249.

[6] Ramadhan, D. M. 2014. Kajian Histopatologi Hepar Ayam Buras (Gallus domesticus) yang Terserang Leucocytozoonosis (Leucocytozoon sabrazesi) [Skripsi]. Fakultas Kedokteran Hewan. Universitas Airlangga.

[7] Ratnadewi, Y. 2015. Jawa Barat Masih Berisiko terhadap Penyakit Malaria. http://pikiran-rakyat.com/jawa-barat/2015/05/07/326420/jawa-barat-masihberisiko-terhadap-penyakit-malaria. [24 Maret 2017]

[8] Rosdesiana, D. 2016. Prevalensi Protozoa Darah pada Burung Puyuh (Coturnix coturnix) di beberapa Kecamatan di Kabupaten Jombang. [Skripsi]. Fakultas Kedokteran Hewan. Universitas Airlangga.

[9] Rusqiyati, E. A. 2014. Dinkes Yogyakarta Selidiki Vektor Malaria. http://jogja.antaranews.com/berita/327018/ dinkes-yogyakarta-selidiki-vektor-malaria. [24 Maret 2017]

[10] Sinulingga, L. R., Darjono, J. 2004. Dinamika Perkembangan Leucocytozoon caulleryi dalam Darah Perifer Ayam Potong. J. Sains Vet. 22(1): 14 - 17.

[11] Swayne, D. E., Glisson, J. R., McDougald, L. R., Nolan, L. K., Suarez, D. L., and Nair. V. 2013. Disease of Poultry 13th Edition. Blackwell Publishing Ltd. Oxford. 1189-1190.

[12] Tabbu, C. R. 2002. Penyakit Ayam dan Penanggulangannya: Penyakit Asal Parasit, Non Infeksius, dan Kompleks Vol 2. Kanisius. Yogyakarta. 36, 38, 58.

[13] Wiryawan, W. 2002. Mengendalikan Penyakit Mirip Malaria (Leucocytozoonosis): Waspada Leucocytozoonosis pada Unggas. Mengendalikan Penyakit Unggas. Infovet Ed. 1. 234 - 237. 